\title{
Fish use of intertidal mangrove creeks at Qeshm Island, Iran
}

\author{
M. Shahraki ${ }^{1, *}$, U. Saint-Paul ${ }^{1}$, U. Krumme ${ }^{2}$, B. Fry ${ }^{3}$ \\ ${ }^{1}$ Department of Ecology, Leibniz Center for Tropical Marine Ecology (ZMT), 28359 Bremen, Germany \\ ${ }^{2}$ Thünen Institute of Baltic Sea Fisheries, 18069 Rostock, Germany \\ ${ }^{3}$ Australian Rivers Institute, Griffith University, Southport, QLD 4222, Australia
}

\begin{abstract}
Habitat use by fish in intertidal mangrove creeks is relatively unstudied in the Persian Gulf. We investigated the role of temporal variations and creek elevation in shaping fish community structure in intertidal mangrove creeks in the Strait of Hormuz, Qeshm Island, Iran (western Indian Ocean). Block net sampling was carried out to examine the influence of 3 types of temporal dynamics on patterns of fish diversity and biomass. Tides, diel day/night variations, and season all proved important for fish dynamics. The fish assemblage of 29 species was dominated by Mugilidae, which constituted $62 \%$ of biomass and $41 \%$ by abundance. Although the most abundant species occurred in all creeks and months, the number of species, community biomass and abundance of individuals were significantly influenced by tide and day/night cycles, with highest values during nighttime spring tides and lowest values during daytime neap tides. Gut content studies showed that fish accessing marsh surfaces on nighttime spring tides generally had $75-100 \%$ full guts, indicating trophic use of mangrove areas. The findings from this meso-tidal arid area generally agree with previous studies of mangrove creeks from wetter tropical sites, but there were some exceptions. Notably, fish community abundance and biomass in February winter conditions were highest during nighttime neap tide conditions, instead of during nighttime spring tide conditions. This neap tide maximum was associated with a relatively greater dominance of resident fish species during winter, but may also indicate some temperature-related differences in fish use of mangroves that are at the northernmost regional limit of their distributions at Qeshm Island.
\end{abstract}

KEY WORDS: Intertidal mangrove creeks · Fish community $\cdot$ Tidal cycle $\cdot$ Persian Gulf $\cdot$ Western Indian Ocean

\section{INTRODUCTION}

Mangrove ecosystems are important habitat for fish worldwide (Robertson \& Duke 1990, Sasekumar et al. 1992, Nagelkerken 2009). However, the importance of mangroves to fish populations varies among systems according to several environmental conditions (Blaber \& Blaber 1980, Blaber 2000, Faunce \& Serafy 2006). This study investigated mangroves of the Persian Gulf that occur under extreme conditions of aridity and large $\left(>20^{\circ} \mathrm{C}\right)$ seasonal variations in temperatures, at the northern edge of mangrove distributions in the Indian Ocean. This harsh environ- mental setting involves high salinities and restricts mangrove diversity to 2 species (Avicennia marina and Rhizophora mucronata) in this arid region (AlKhayat \& Jones 1999, Sheppard et al. 2010). This study assessed the fish use of mangrove creeks in this environment.

There are many regular features of intertidal mangrove forests. Mangrove forests are alternately inundated and exposed by tides, and fish have to cope with variations in tidal habitat availability (Quinn \& Kojis 1987, Rooker \& Dennis 1991, Sheaves 2005). The regular changes in water level may cause significant changes in mangrove-associated fish fauna on 
meso-tidal and macro-tidal coasts (Davis 1988, Wilson \& Sheaves 2001, Krumme 2009). Tidal- and dielrelated patterns of fish assemblages are well documented for humid mangroves, e.g., in Brazil and Thailand (Krumme et al. 2004, Krumme \& Saint-Paul 2010, Krumme et al. 2015). In the western Indian Ocean, only a few studies have examined how mangrove fish assemblages are affected by the influence of tides (Laroche et al. 1997, Weis et al. 2009). Strong diel components involved in fish use of mangroves were also found in Madagascar (Laroche et al. 1997). This study examined the tidal and day/night dynamics that help shape intertidal fish assemblages of arid mangroves.

In addition to tide and day/night factors, temperature may also be important for fish use of mangrove habitats. Tidal influences of fish assemblages have been mostly studied in regions with stable temperatures (Vance et al. 1996, Rönnbäck et al. 1999). This study included winter and summer sampling to examine the effects of a $>20^{\circ} \mathrm{C}$ seasonal temperature variation on fish use of mangroves.

The elevation of tidal creeks was also studied as a factor possibly influencing fish distributions (Kneib \& Wagner 1994, Allen et al. 2007). Along the Iranian coast of the Persian Gulf, intertidal mangrove creeks are generally flooded during high tide and become completely exposed at low tide. However, intertidal creeks can be located at differing elevations, which affects the timing and depth of inundation during high water. Intertidal creek use by fish can be influenced by creek drainage characteristics (Kneib 1997). Fish use of the intertidal salt marsh creeks of South Africa and California has been reported previously (Paterson \& Whitfield 2003, Allen et al. 2007), but there are few reports concerning creek drainage effects on the dynamics of intertidal mangrove fish assemblages (Lugendo et al. 2007a). Thus, it was important to understand the role of creek elevation on fish habitat use in the mesotidal regimes of Qeshm Island.

This factorial-design study examined temporal patterns of intertidal mangrove fish assemblage structure along the southern Iranian coast, addressing: (1) the taxonomic composition of intertidal mangrove fish fauna, and (2) tide, diel, and monthly related patterns of fish use of mangrove creeks that were located at different elevations. The number of fish species and their abundance and biomass were expected to differ in accordance with tides, day/night cycles, seasons, and interactions between these factors in mangrove creeks of different elevations.

\section{MATERIALS AND METHODS}

\section{Sampling sites}

The study was carried out at Qeshm Island, on the Iranian coast of the Persian Gulf $\left(26.8^{\circ} \mathrm{N}, 55.75^{\circ} \mathrm{E}\right)$ (Fig. 1). Details of the study area can be found in Shahraki et al. (2014). Four mangrove-lined creeks, flowing into a main channel, were chosen as sampling sites to test the fish use of creeks relative to tidal cycles. Creeks 2 and 3 were situated at a lower elevation and were larger in size (low-lying creeks) than the high-lying Creeks 1 and 4 (Fig. S1 in the supplement at www.int-res.com/articles/suppl/m542p153_supp. pdf). High-lying creeks were smaller and had a lower flooding frequency than low-lying creeks; this resulted in less time available for fish to use these highlying creeks. Tides were semidiurnal, with 2 highs and 2 lows per day, and tidal amplitude averaged $2.5 \mathrm{~m}$. Tides selected for study were night tides that fell during the later part of the night, reaching low tide at dawn, and day tides that fell during the afternoon, reaching low tide at dusk. Corresponding fish sampling was at dawn for the night tides and at dusk for the day tides.

\section{Sampling design}

Fish were sampled from the 4 intertidal creeks with block nets (15-25 m in length, $4 \mathrm{~m}$ high; $12 \mathrm{~mm}$ stretched mesh size) lifted at slack high water during 3 lunar cycles in December 2011-January 2012, February-March 2012 and August-September 2012. The nets were deployed at low tide along the mouth of the creeks and were buried in the sediment and held in place with wooden stakes. The nets were rolled down to the level of the sediment and left until high tide. Net lengths were adjusted to stretch across the entire widths of the tidal creeks. At high tide, the tops of the nets were lifted onto wooden stakes. During the following low tide, when the creeks were almost empty, the fish were collected (Shahraki \& Fry 2015). The block net method is commonly used for fish collection in mangrove studies (e.g. Thayer et al. 1987, Barletta et al. 2003), and this method is regarded as highly efficient in capturing fish that use intertidal habitats (Bozeman \& Dean 1980). Block net sampling is usually considered an area-based method, but results are reported here both on a per sample and per area $\left(\mathrm{m}^{-2}\right)$ basis. The per sample results are given mostly for comparison with other studies (see 'Discussion'). 
Overall 96 block net samples were taken (4 intertidal mangrove creeks $\times 3$ lunar cycles $\times 4$ lunar phases $\times 2$ times of day). Sampling targeted the 4 most important combinations of tidal amplitude (and lunar phase) and daylight conditions: spring tide-night (SN; new moon/full moon night), spring tide-day (SD; new moon/full moon day), neap tide-night (NN; wax/wane moon night) and neap tide-day (ND; wax/wane moon day). Lunar phases were considered as replicates for spring and neap tide. SN and NN sampling took place in the early morning, when fish had entered the creeks during the nightly flood tide and were leaving on the morning ebb tide. SD and ND sampling were carried out in the evening, when fish had entered with the afternoon flood tide and were leaving during the first part of the night. The time of each sampling was chosen according to the tide tables for the area (Qeshm Meteorological Station, data received as personal communication).

Fish were collected during low tide and transported on ice to the laboratory. The high-lying creeks dried out at each tide. However, the low-lying creeks still contained water at neap low tide. In this instance, a small hand net was used to collect all the fish behind the block nets. Collected fishes were identified to the lowest possible taxonomic level (Fischer \& Bianchi 1984, Kuronuma \& Abe 1986, Assadi et al. 1997), counted, and weighed (wet weight;

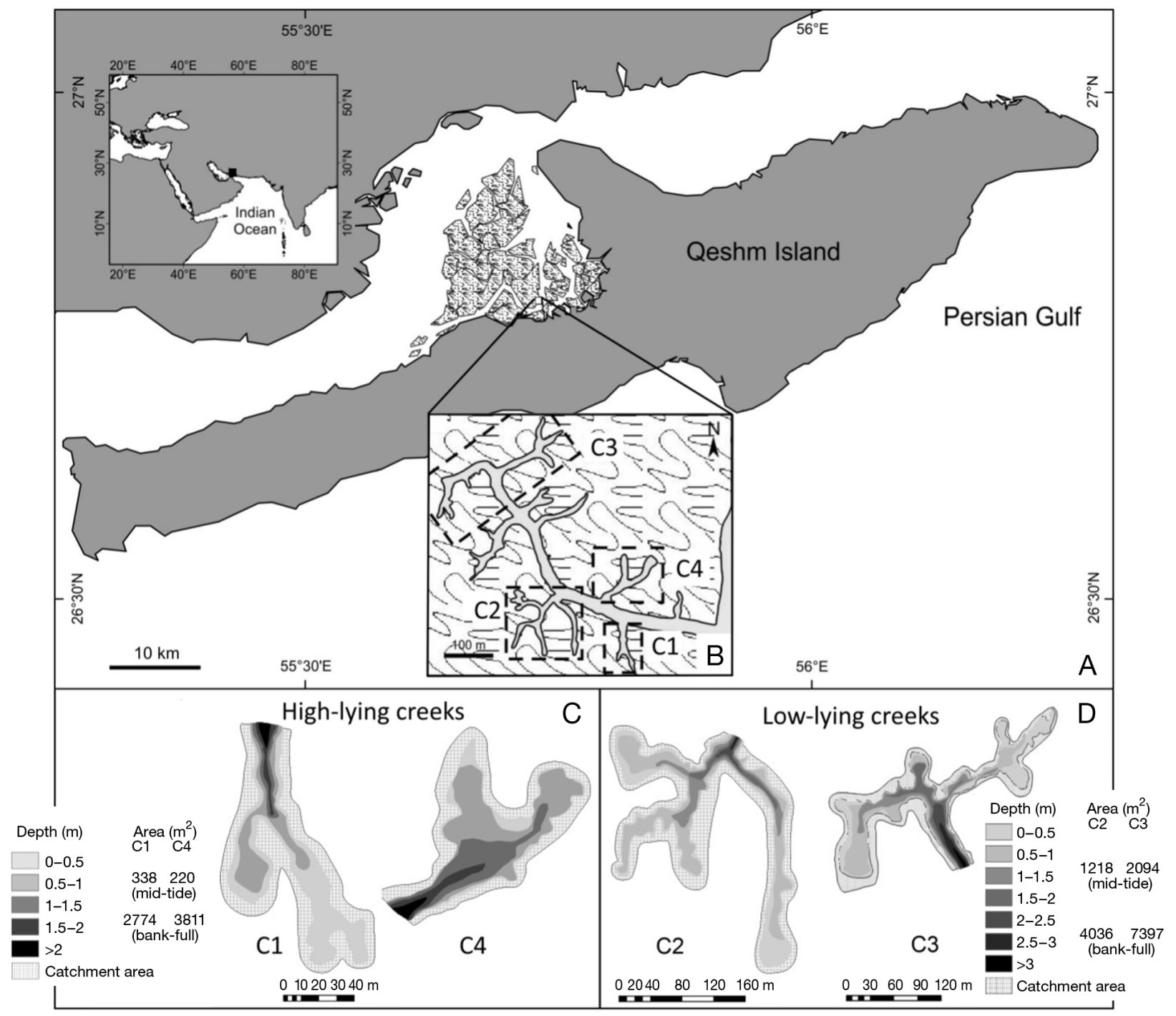

Fig. 1. (A) Location of the study area at Qeshm Island, Strait of Hormuz, Iran. (B, inset) Mangroves in light gray with the main channel and the 4 intertidal creeks (C1-C4, dashed rectangles). Bathymetric maps of (C) high-lying Creeks 1 and 4 and (D) low-lying Creeks 2 and 3. The total inundation areas of the creeks are indicated at mid-tide (beyond 1 and $1.5 \mathrm{~m}$ depths for the high- and low-lying creeks, respectively) and at full bank (beyond 2 and $3 \mathrm{~m}$ depths for the high- and low-lying creeks, 
$g \pm 0.1$ ). Fish species were assigned to resident or transient categories based on available literature (Day 1989, Elliott et al. 2007, Froese \& Pauly 2012). Given the fact that the residency status of only a few species collected in this study was available in the literature, we categorized the fish residency based on information from the same family and genus and considered personal expert consultations (M. Elliott pers. comm.) and also data from Ley et al. (1999) and Ley \& Halliday (2007).

Stomach fullness of 4 species (Acanthopagrus latus, Pomadays kaakan, Liza klunzingeri, Lutjanus johnii) was determined to assess whether fish feeding was related to tides and time. For that analysis, a total of 304 stomachs ( 20 individuals from different tidetime of days from each species) were selected. Stomach fullness was visually assigned to 1 of 4 fullness categories: empty or nearly empty, $0-25 \%$ (1), $25-50 \%(2), 50-75 \%$ (3), or nearly or completely full, $75-100 \%(4)$.

For each sampling event, surface water temperature was measured (WTW Multi 3430), and tidal height was recorded at the mouth of the creeks at high water (tidal gauge). Mean $\mathrm{pH}$ values $( \pm \mathrm{SD})$ were $8.1 \pm 0.2$, and salinity averaged $38.3 \pm 0.5$ throughout the sampling period (Shahraki et al. 2014). The transparency of the water measured by Secchi disk was $52 \pm 2 \mathrm{~cm}$. Additionally, a HOBO water data level logger (U20-001-01-Ti) was used to assess the interaction between water level changes and water temperature in the main mangrove channel in August (the HOBO did not operate in December or February). This device measured water level (water level accuracy: $\pm 0.5 \mathrm{~cm}$ ) and water temperature (temperature accuracy: $\pm 0.44^{\circ} \mathrm{C}$ ) every $15 \mathrm{~min}$, resulting in information about changes in the water height and temperature over several spring and neap tide cycles.

\section{Creek attributes}

Bathymetric surveys of the creeks were carried out at the end of the sampling period to assess the local topography with respect to tidal inundation and drainage patterns. The survey included measuring water levels at horizontal transects for each creek and drawing approximate inundation areas on a grid map in the field using a tape measure, GPS, and a compass. This information was used with GIS software to produce a bathymetric map of each creek (Fig. 1). The map was sourced using the GNU Lesser General Public License. Intertidal creek depth points were added using GPS waypoints from the drainage areas.
A topographic height was assigned to each depth polygon in attribute tables. All depth polygons were transformed to raster data to calculate water surface area and volume for each creek with high-resolution 3-dimensional models. Relationships between high water level and inundated area and volume were established (Fig. S2 in the supplement). Abundance and biomass for each species per sample were converted to abundance and biomass per square meter by dividing by the respective inundation area for each creek.

Qeshm mangrove forests are flooded only during spring tides. The low-lying creeks were characterized by having greater water depths (mean $\pm \mathrm{SD}$; $0.37 \pm 0.2 \mathrm{~m}$ ) in relation to mean sea level and greater time of inundation during high-water periods when compared to the high-lying creeks. GIS-generated estimates indicated that the relationship between surface area, volume, and intertidal water level increased slowly until an approximately 1-1.5 m water level rise at the mouth of the creeks and inundation was still restricted to the creek network. At this water stage, mean drainage areas were 338,815 , 2937 and $1281 \mathrm{~m}^{2}$ for Creeks 1, 2, 3, and 4, respectively. Beyond 2-3 m water level rise, the water left the creek network and the mangrove creeks became flooded (Fig. S2). Mean drainage areas were then 2774, 6481, 11460, and $3811 \mathrm{~m}^{2}$ for Creeks 1, 2, 3, and 4 , respectively.

\section{Data analysis}

EstimateS software was used to produce rarefaction curves and estimates of species richness for each creek (Colwell 2009). Species richness between the factors month and tide-time of day combination (SN, $\mathrm{SD}, \mathrm{NN}, \mathrm{ND}$ ) and also the stomach fullness difference between SN, SD, NN, and ND were analyzed with Kruskal-Wallis 1-way analysis of variance on ranks (for each factor), followed by a Tukey test in SigmaPlot 12.5. The Shapiro-Wilk test was used to test for normality.

The effect of water conditions on intertidal fish abundances or biomass was assessed with 4 -way permutational multivariate analysis of variance (PERMANOVA) model. Factors included: location (fixed, 2 levels: high-lying and low-lying creeks), creek nested in location (random, 4 levels: 1, 2, 3, 4), tide-time of day combination (fixed, 4 levels: SN, SD, NN, ND) and month (fixed, 3 levels: December, February, August). Additionally, differences among fixed factors were analyzed with pairwise comparisons, 
and, in the case of location, Monte-Carlo generated $p$-values were used because there were inadequate unique permutations possible to determine permutational p-values (Anderson et al. 2008). Canonical analysis of principal coordinates (CAP) was applied as a constrained ordination procedure to visualize patterns revealed by PERMANOVA. CAP finds axes through multivariate data clouds to maximize the differences among a priori groups (Anderson et al. 2008). The species most responsible for differences were identified based on relatively high correlation $(|r|>0.4)$ with the CAP axes (Anderson \& Willis 2003, Willis \& Anderson 2003). Analyses were performed on square-root-transformed data and based on BrayCurtis distances.

Pearson correlation tests were used in Statistica 11 to test whether high water level and surface water temperature correlated with intertidal fish abundance and biomass per sample.

\section{RESULTS}

\section{Species composition and richness}

A total of 5954 individuals from 29 fish species and 22 families were caught in 96 block net samples. Half of the species (15 of 29 species) were abundant with 10 or more individuals. The most speciose families were Clupeidae (4 species), Haemulidae, Sparidae, Lutjanidae, and Gobiidae (2 species each). The most abundant species were Liza klunzingeri $(41 \%$, Mugilidae), Leiognathus daura (18\%, Leiognathidae), Pentaprion longimanus (10\%, Gerreidae), and Thryssa vitrirostris (8\%, Engraulidae). All other species accounted for the remaining $20 \%$ of the total abundance, each with $<5 \%$. In terms of catch biomass, $L$. klunzingeri $(62 \%), T$. vitrirostris $(8 \%)$, and Acanthopagrus latus (5\%, Sparidae) made up $75 \%$ of the catch (Table 1). Transient species represented $82 \%$ of the species and $>85 \%$ of total abundance and biomass (Table 1).

The most abundant species (relative abundance of $>1 \%$ ) occurred in all creeks (Table 1). Also, the observed number of species was similar at 13-16 species when 500 individuals were considered for comparisons between creeks (Fig. 2).

Species richness differed between tide-time of day (Kruskal-Wallis (KW) test, $H=32.7, \mathrm{p}<0.001$; Tukey's test, SN $>$ ND) and between months (KW test, $H=6.06, \mathrm{p}<0.05)$. Significantly more species were captured at SN, while ND had the lowest species numbers (Fig. 3). The median number of species at
SN was 7 (the $25^{\text {th }}$ and $75^{\text {th }}$ percentiles were $6 \& 8$ ), while for the other tide and time combinations the median ranged between 4 and 5 (Fig. 3). The median numbers of species were 4,5 and 6 for December, February and August, respectively, but these median values were not significantly different (Fig. 3). However, detailed species data did show significant presence/absence differences among months and tidal and diel cycles. For example, Sardinella longiceps was not found at SN and Pomadays kaakan did not occur at NN. Also, some rare species with a relative abundance of $<1 \%$ occurred mostly at $\mathrm{SN}$, e.g. Upeneus sulphureus, Hemiramphus archipelagicus, and Pseudosynanceia melanostigma (Table 1). Five species (L. klunzingeri, $T$. vitrirostris, A. latus, $P$. kaakan, and Lutjanus johnii) made up $85 \%$ of the catch biomass at SN. Some resident species, Sardinella longiceps and Sardinella gibbosa (Clupeidae), were absent in August, whereas these species were more abundant in February (Table 1). The NN/SN ratios of biomass for the resident species were 2.4 in February and 0.2 and 0.5 in December and August, respectively.

The monthly variations in species richness were mostly related to the seasonally transient species. In detail, Scomberoides lysan, $H$. archipelagicus, and $U$. sulphureus only occurred in August; Pseudorhombus elevatus, Eleutheronema tetradactylum, Strongylura strongylura, Abalistes stellatus, and Acanthopagrus cuvieri were only found in February, and P. melanostigma only in December. The most abundant species changed rank between months (Fig. S3 in the supplement).

\section{Spatio-temporal patterns}

PERMANOVA results for the effect of month were highly significant (Table 2), with significant differences between February and August (February $>$ August, $\mathrm{p}<0.05$; Fig. 4). Highest abundance and biomass per sample and per square meter were observed at SN (Fig. 5). Also, tidal and diel variations were highly significant $(p<0.001)$ in PERMANOVA results (Table 2). The pairwise comparisons for abundance and biomass per sample and per square meter showed higher values at SN compared with ND $(t>$ $3.1, \mathrm{p}<0.05)$. While the tide-time of day combination had a strong effect on the fish assemblage composition, the effect was not constant between months (Fig. S4 in the supplement). For instance, unlike other NN conditions, high biomass per sample and per square meter and abundance per square meter 


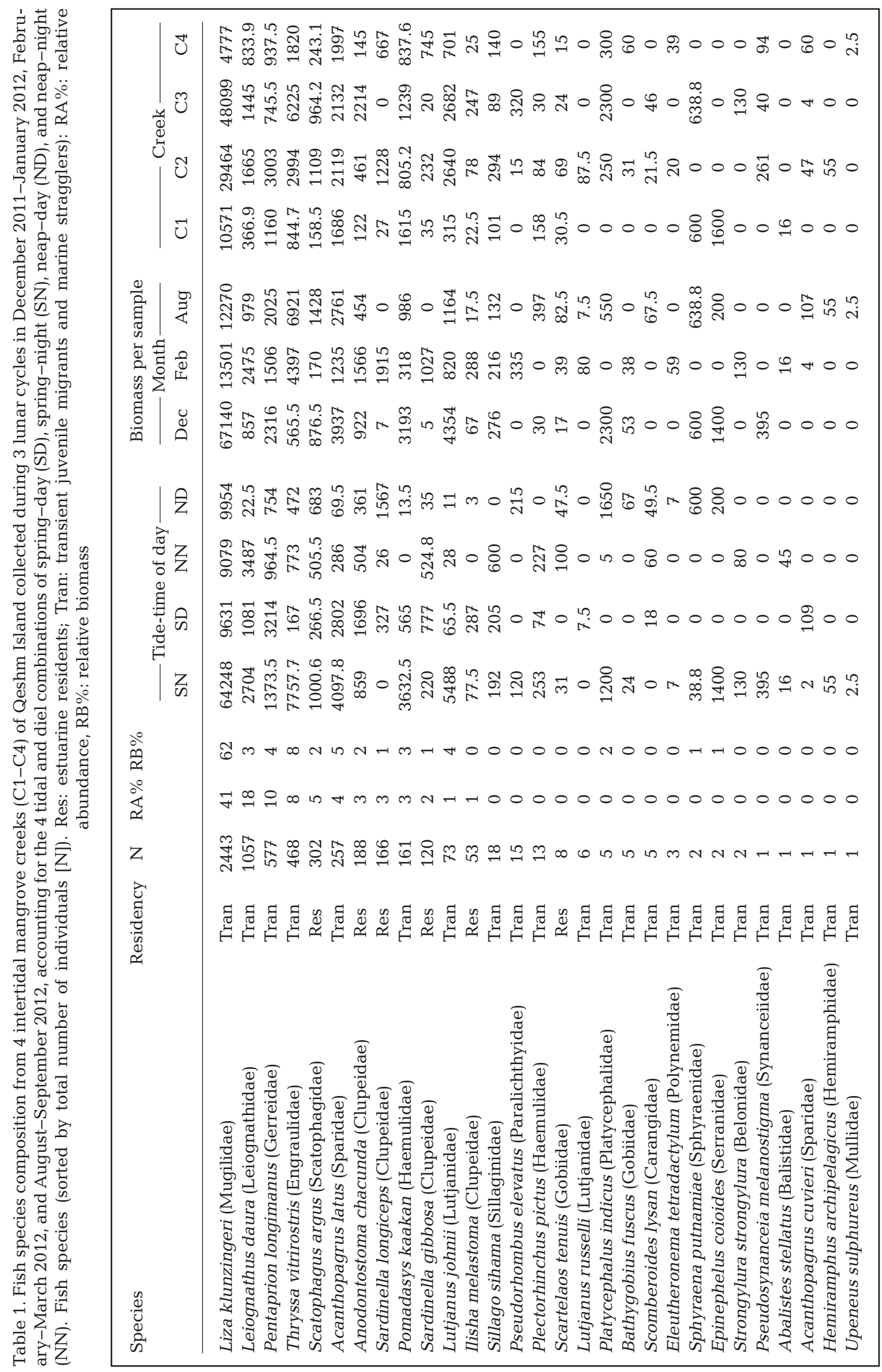



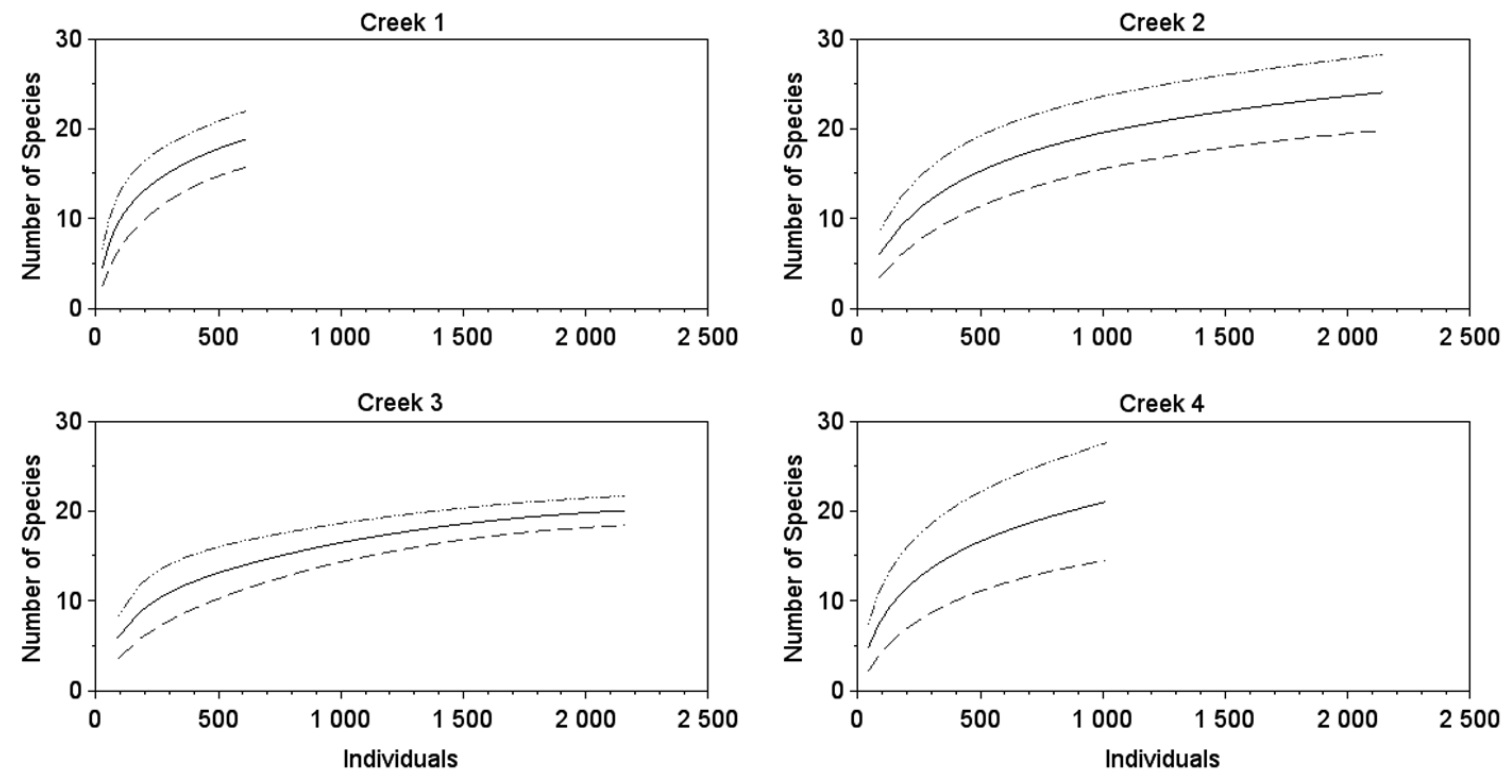

Fig. 2. Individual-based rarefaction curves of fish species caught in 4 mangrove-lined creeks sampled in different combinations of tidal and diel cycles during 3 months (December 2011, February and August 2012) at Qeshm Island, Iran. Dashed lines indicate $95 \%$ confidence intervals

occurred at NN in February. Also, resident species were more abundant in February than in other months (Table 1). The interactions between months and tides were also significant $(\mathrm{p}<0.05)$ in all cases (per sample and per area) in PERMANOVA (Table 2).

Creek-level variations (nested in location) were significant in PERMANOVA results at the 0.006-0.03 p-level in 3 of 4 cases (Table 2). Mean abundance and biomass per sample were higher at Creeks 2 and 3, but inconsistent patterns were observed when the biomass and abundance were expressed per square meter (Fig. S5 in the supplement). This indicates that

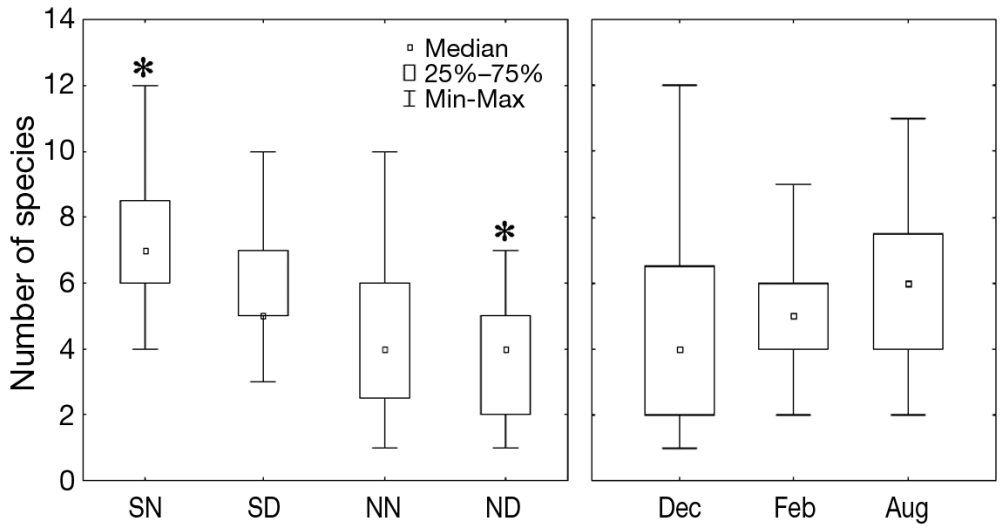

Fig. 3. Median number of fish species captured at spring tide-night (SN), spring tide-day (SD), neap tide-night (NN), and neap tide-day (ND) and in 3 months (December 2011, February and August 2012) in intertidal mangrove creeks ( $\mathrm{n}=96$ samples). The 25 to $75 \%$ quartiles and minimum and maximum values are shown. Asterisks indicate significant differences between groups (SN > ND, p < 0.05) low-lying creeks do not support more fish abundance and biomass per square meter. Statistical tests showed no significant interactions between creeks and tides or between creeks and months (Table 2). Overall, creeks and associated interactions showed fewer significant differences than the time-related factors that included tides, day/night, and season (Table 2).

Further examination of the significant abundance and biomass factors in PERMANOVA, with the CAP routine, indicated low overall allocation success for the factor month (Table S1 in the supplement). CAP only allocated the samples according to the factor tide and time of the day (Fig. 6). A. latus, $L$. daura, and $T$. vitrirostris were positively correlated with the high water level (spring tide samples), as indicted by the correlation coefficients of $0.4,0.5$, and 0.5 , respectively, whereas $P$. longimanus was negatively correlated $(-0.5)$ with the high water level.

Total abundance and biomass were significantly positively related to the high water level $(\mathrm{r}=0.4$ and $0.2, \mathrm{n}=96, \mathrm{p}<$ 0.05 ) and negatively correlated to the surface water temperature $(\mathrm{r}=-0.09$ and $-0.1, \mathrm{n}=96, \mathrm{p}<0.05)$. Spring tide was indicated by higher water levels in all months (Fig. S6a in the supplement), and the lowest water temperatures were detected at SN and $\mathrm{NN}$ in all months (Fig. S6b). 


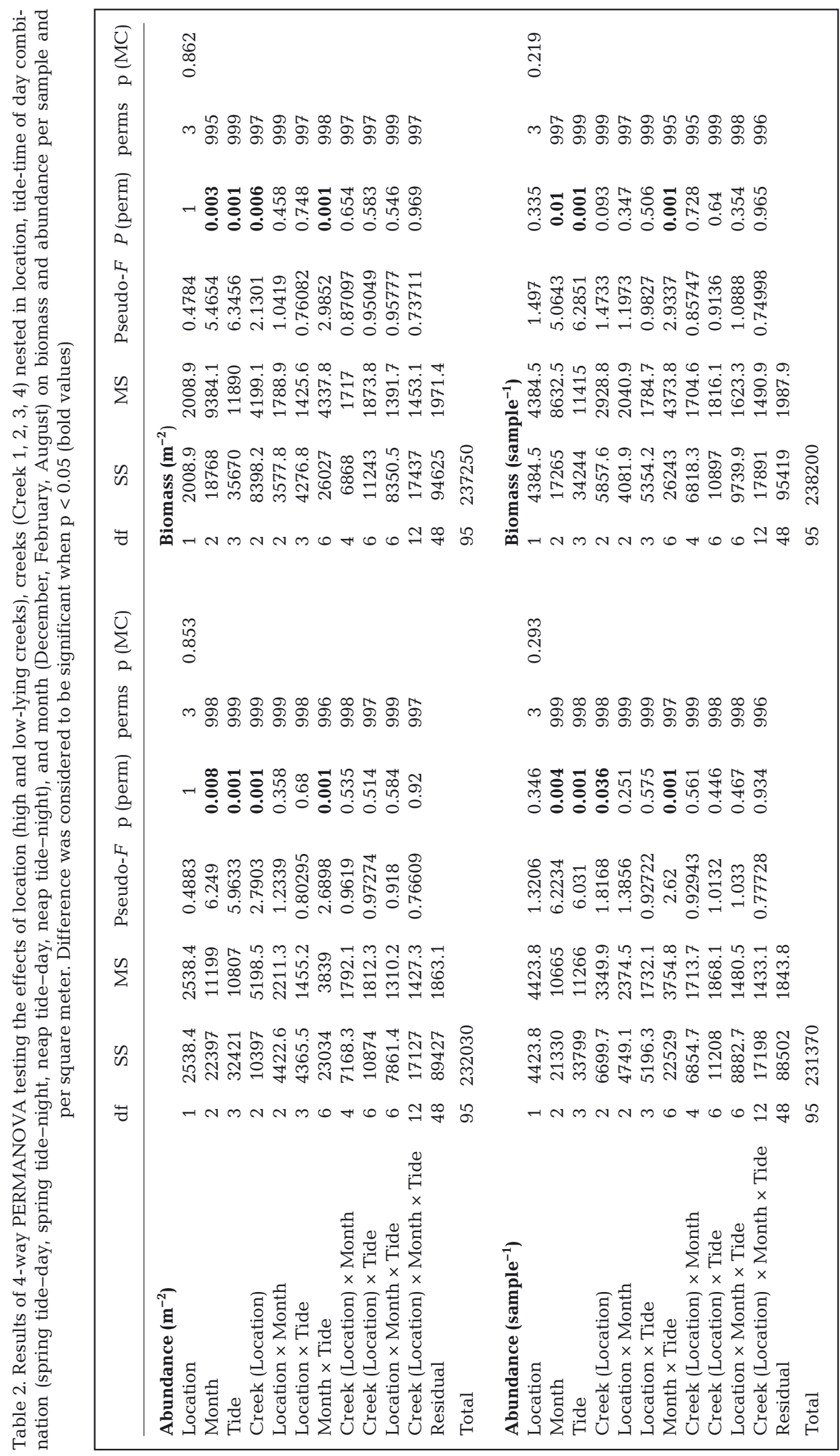



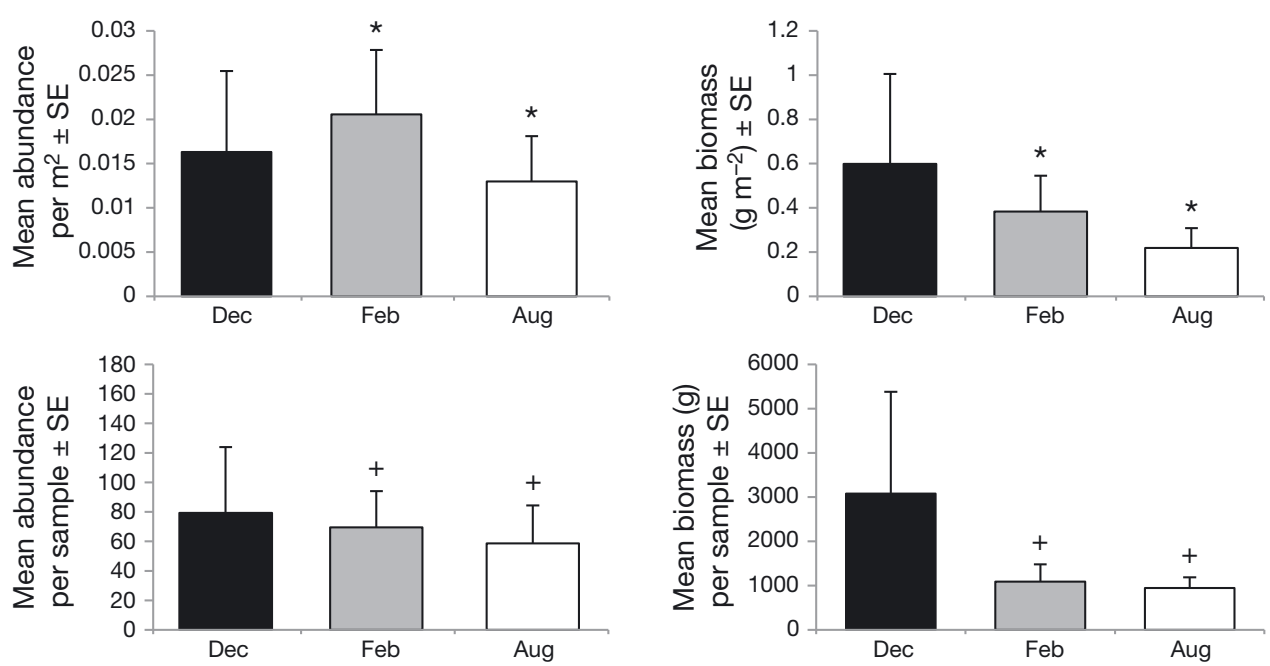

Fig. 4. Mean fish abundance and biomass per sample and per square metre $( \pm$ SE) during different months (December 2011, February and August 2012) from intertidal mangrove creeks at Qeshm Island, Iran. Asterisks indicate significant differences between groups (February $>$ August, $\mathrm{p}<0.05$ ). Plus symbols indicate differences existed at $\mathrm{p}=0.07$
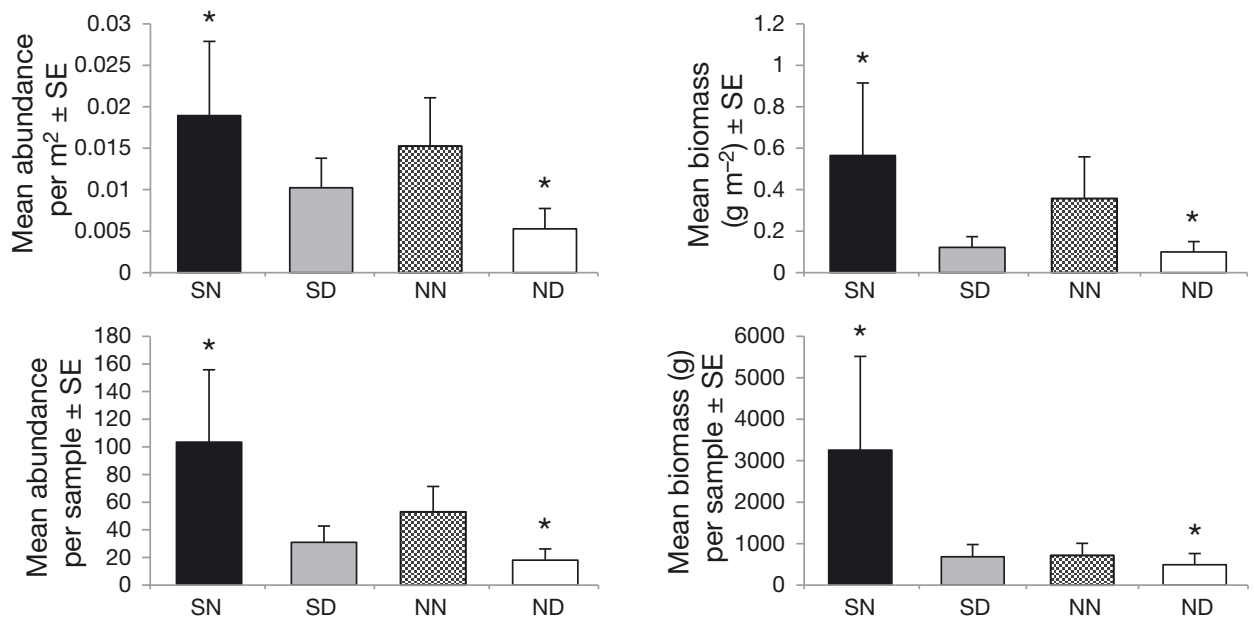

Fig. 5. Mean fish abundance and biomass per sample and per square meter $( \pm \mathrm{SE})$ at different combinations of tidal-diel cycles: spring tide-night (SN), spring tide-day (SD), neap tide-night (NN), and neap tide-day (ND) from intertidal mangrove creeks at Qeshm Island, Iran. Asterisks indicate significant differences between groups $(\mathrm{SN}>\mathrm{ND}, \mathrm{p}<0.05)$

The results of the HOBO water level logger, operated in August, showed that the water temperature cooled during nightly low water and heated during the daytime low-water period, with higher daytime values at spring tide (up to $36^{\circ} \mathrm{C}$ ) than at neap tide $\left(33.5^{\circ} \mathrm{C}\right)$. Lowest water temperatures were measured during nightly neap tide low water $\left(31^{\circ} \mathrm{C}\right.$; Fig. $\mathrm{S} 7$ in the supplement).

Stomachs of all 4 common fish species selected for study were generally 75 to $100 \%$ full on spring tide nights. Stomachs were fuller at night than during the day $(\mathrm{p}<0.05)$. Stomachs at $\mathrm{SN}$ were fuller than at $\mathrm{SD}$,
$\mathrm{ND}$, and NN $(\mathrm{p}<0.05)$. This indicates more successful feeding at night and also at spring tide. Stomach contents of A. latus, P. kaakan, and L. johnii consisted mostly of crabs, while the stomachs of L. klunzingeri were filled by sediment and algae (M. Shahraki unpubl. data).

\section{DISCUSSION}

Fish assemblages occupying Qeshm intertidal mangrove creeks are characterized by low species 


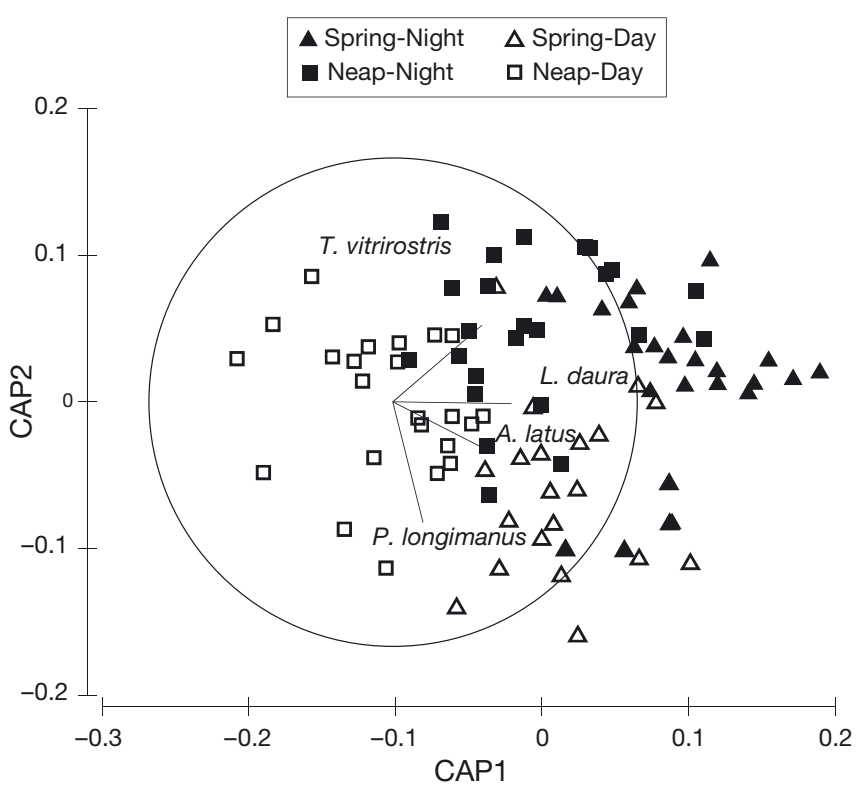

Fig. 6. Canonical analysis of principal coordinates (CAP) of Qeshm mangrove fish assemblages (biomass $\mathrm{m}^{-2}$ ) yielded 2 axes regarding the factor tide-time, with squared canonical correlations of $\delta_{1}^{2}=0.68$ and $\delta_{2}{ }^{2}=0.40$. Symbols represent individual biomass values $\left(\mathrm{g} \mathrm{m}^{-2}\right)$, and vectors show individual species' correlations with the 2 CAP axes where $|r|>0.4$. See Table 1 for full species names

diversity. The number of fish species in the mangrove intertidal creeks of Qeshm Island is lower than that in other comparable intertidal shallow water habitats of the Indo-Pacific (Table 3). In the Indo-Pacific, fish species richness varies from 29 in Iranian mangroves to 136 species in Malaysian and Thai mangroves

Table 3. Comparison of the number of species and families from mangroves in the Indo-West Pacific divided into 3 regions according to Duke et al. (1998): East Africa, Indo-Malesia and Australasia; studies sorted by descending year of study. NA: not available

\begin{tabular}{|lccl|}
\hline Indo-West Pacific & Species & $\begin{array}{c}\text { Species/ } \\
\text { Family }\end{array}$ & Source \\
\hline East Africa & & & \\
Tudor creek, Kenya & 83 & 2.1 & Little et al. (1988) \\
Tulear Lagoon, Madagaascar & 60 & 1.7 & Laroche et al. (1997) \\
$\begin{array}{l}\text { Chwaka Bay, Zanzibar } \\
\text { Qeshm Island, Iran }\end{array}$ & 44 & 1.6 & Lugendo et al. (2007b) \\
Indo-Malesia & 29 & 1.3 & Present study \\
$\begin{array}{l}\text { Selangor, Malaysia } \\
\text { Luzon, Philippines }\end{array}$ & 119 & NA & Chong et al. (1990) \\
$\begin{array}{l}\text { Sikao Creek, Trang Province, } \\
\quad \text { Thailand }\end{array}$ & 137 & 1.7 & Rönnbäck et al. (1999) \\
$\begin{array}{l}\text { Sikao Creek, Trang Province, } \\
\quad \text { Thailand }\end{array}$ & 89 & 2.1 & Tongnunui et al. (2002) \\
$\begin{array}{l}\text { Australasia } \\
\text { Solomon Islands }\end{array}$ & & & Ikejima et al. (2003) \\
$\begin{array}{l}\text { Alligator Creek, Australia } \\
\text { Embley River, Australia }\end{array}$ & 136 & 3.2 & Blaber \& Milton (1990) \\
& 55 & 1.8 & Vance et al. (1996) \\
\hline
\end{tabular}

(Table 3 and references therein). The ratios of species to families also show the low diversity within families in the Persian Gulf and African mangroves (Table 3). In contrast, these values are high in the humid region Malaysian and Thailand mangroves. Overall the diversity of fish may be closely linked to the environmental conditions, e.g., the lack of fresh water and rainfall in the Persian Gulf as compared to the high precipitation in Southeast Asia. In Qeshm mangroves, the Mugilidae, Leiognathidae, and Engraulidae fish families dominate in terms of abundance. Mugilidae are also an abundant family in the shallow water intertidal habitats of Kuwait (Wright 1988, Wright 1989), indicating that mullets are dominant along the coast of the Gulf region. The dominance of Mugilidae is likely linked to the benthic algae and sediment-based food webs in this arid region (Shahraki et al. 2014).

Of the fish species found, 6 were resident and 23 were transient, so that most fish used Qeshm mangroves as a temporary habitat. In contrast, a study in Florida reported that residents may account for $>90 \%$ of the species in mangroves (Ley et al. 1999). Ley et al. (1999) observed more resident species in winter when the water temperature was low. Therefore, the high water temperatures that prevail most of the year in this region might explain the low fish residency in Qeshm mangroves. Additionally, studies in the Indo-Pacific and western Atlantic have highlighted the effects of salinity in fish distributions and residency (Barletta \& Blaber 2007). For example, in the Embley estuary in North Australia, where salinities are uniform and relatively high, marine immigrants (transients) dominate fish guilds. In contrast, most species are categorized as estuarine species (fresh water and marine stragglers) in the Caeté estuary in North Brazil, where a wide range in salinity gradients exists (Barletta \& Blaber 2007, Barletta et al. 2008, Barletta \& Saint-Paul 2010). In particular, these studies reported higher numbers of resident species during the wet season, when the salinity was very low. Thus, the environmental parameters salinity and temperature are among the main factors influencing fish residency and diversity in mangrove areas, reflecting the arid region of this study.

Seasonal variations in species richness were mostly due to the presence of more minor transient species, al- 
though resident species from the family of Clupeidae were largely absent in summer. Most highly abundant species were found during all months. Overall, these seasonal patterns indicate the highest fish abundance and biomass in the cold winter months. The results contrast those of mangrove studies in the western Pacific Ocean (e.g. Australia and Taiwan), which found higher fish abundance in warmer seasons (Laegdsgaard \& Johnson 1995) and higher fish diversity with increases in water temperature (Lin \& Shao 1999). Because of the diverse results across regions, further research is needed regarding the seasonal patterns of mangrove fish distribution.

The numbers of species, abundance, and biomass were highest during nighttime spring tide inundations in Qeshm mangroves, even though lower numbers of all the top 12 species (relative abundance of $>1 \%$ ) were also present during the day. Especially the Mugilidae (Liza klunzingeri), Leiognathidae (Leiognathus daura), Engraulidae (Thryssa vitrirostris), Haemulidae (Pomadasys kaakan), and Lutjanidae (Lutjanus johnii) dominated spring nighttime samples. The high nighttime dominance of these species might be related to the feeding strategy of some of these fish, as reported by Nagelkerken et al. (2000) and Ley \& Halliday (2007). In Australia, diel variations in subtidal mangrove fish assemblages are related to the nocturnal activities of benthic fauna, which, in turn, attract nocturnal fish (Ley \& Halliday 2007). The diel cycle is the major rhythm associated with short-term changes in nocturnal Haemulidae and Lutjanidae in non-estuarine systems of the Caribbean Sea (Nagelkerken et al. 2000). Moreover, the temporary nature of most species combined with the stomach fullness index of selected species indicates that the fish migrate to Qeshm Island mangroves to feed under nighttime high-water conditions. Qeshm Island presents mangroves where much larger intertidal areas are inundated at spring than at neap tides. Larger inundation areas during spring tides enable fish to access intertidal forest rich in prey resources that are not available during inundations at neap tides. Other studies also reported that fish from adjacent habitats, such as mud flats and seagrass beds, migrate into the mangroves during high tides to feed (Vance et al. 1996, Sheaves \& Molony 2000). Also, for those transient species with a relative abundance of $<1 \%$ that migrate to mangroves on nighttime spring tides, the higher water level might facilitate the movements of these species to the creeks, with fish relying on tides for transport (Davis 1988). Overall, however, nighttime rather than tide level (spring vs. neap) seemed more important for fish use of man- groves, because even though daytime inundations were deeper and longer lasting than nighttime inundations in Qeshm mangroves (Fig. S6a), fish abundances were almost always lower during the day. These seasonal and diel observations may indicate causal relationships between temperature and fish assemblage structure, and would need further physiological study and modeling for a better understanding of temperature effects on fish use of mangroves.

This work provides the first evidence of the influential role of month on patterns in fish distributions from a low-rainfall mangrove system. The fact that the distributions were not consistent between months further emphasizes the importance of water temperature in the structuring of mangrove fish assemblages at Qeshm Island (Shahraki \& Fry 2015). Similarly, fish habitat use of the intertidal area of Australian mangroves is a function of both month and tidal cycle (Wilson \& Sheaves 2001). Tides are an important factor structuring fish assemblages in many mangroves worldwide (e.g. Vance et al. 1996, Laroche et al. 1997, Ellis \& Bell 2008). These studies show significant separation of spring and neap tide effects on fish assemblages, either per sample or per area basis. For example, greater fish abundance per sample was detected during spring tides in mangroves in Madagascar (Laroche et al. 1997). Likewise, in the macrotidal mangroves in northern Brazil, catch weight of fish (per sample) entering intertidal mangrove creeks was highest during spring tides (Krumme et al. 2004). On the other hand, a study reported more biomass per area of the shrimp Penaeus merguiensis at high tide in northern Australian mangroves (Vance et al. 1996), and Ellis \& Bell (2008) found higher mean numbers of fish at high water per minute in video recordings in mangroves in Florida. Most of these observations were made in mangroves exposed to high precipitation, and there are only few studies of tidally influenced shallow water habitats in low-rainfall systems (Abou-Seedo et al. 1990, Wright et al. 1990). High-frequency trawls on a non-estuarine mud flat in Kuwait Bay showed the significant influence of tidal stage on fish assemblages (Wright et al. 1990). Also, catches were greater during both day and night on falling tides than on rising tides for the intertidal mudflat of the Gulf region (Abou-Seedo et al. 1990). Our results also emphasized the role of tide and diel cycles in shaping the distributions of intertidal mangrove fish assemblages in the low-rainfall system of the Persian Gulf.

Lastly, results showed no spatial differences in fish distribution patterns with respect to creek elevation and size. Fish habitat use was equal across all creeks 
on a per area basis, with the larger Creeks 2 and 3 having more fish because of their larger areas. Also, there was little species difference that could be attributed to creek size; only some resident species (S. gibbosa and $S$. argus) were more dominant in Creeks 2 and 3 . These results contrast those of Desmond et al. (2000), who found that the smallest intertidal creeks were dominated by resident gobiids and cyprinodontids in the salt marshes of southern California (Desmond et al. 2000). Also, a study in salt marshes revealed that broader creeks, with longlasting inundation, supported the greatest use by fish (Allen et al. 2007). Because of these similarities and differences across studies, further research is needed to understand the habitat use of resident species of particular creeks.

\section{CONCLUSIONS}

The study generally agreed with previous work, showing greater fish use of intertidal mangrove habitats during nighttime spring tides when temperatures were cooler and foraging success was high. However, there were 2 unexpected findings in this study of arid Iranian mangrove systems. First, most fish species were transient rather than resident. This may be due in part to the stressful environmental conditions of the relatively high summer temperatures at this northern edge of the mangrove distribution in the western Indian Ocean. Secondly, in the February winter samples, relatively low fish biomass was observed in all samples and the highest numbers of fish occurred during nighttime neap rather than during nighttime spring tides. This high occurred when the fish assemblage was most resident, so that future studies should probably carefully separate resident and transient species when evaluating mangrove creeks as fish habitat.

Acknowledgements. The authors thank H. Shahraki for assistance in the field and laboratory work, the fisherman Saleh Sharifi and his family for assistance during the field work, and M. Dianat (Payame Noor University, Qeshm Island branch), M. Golshani, M. Barani, and M. Parvaresh (Iranian fisheries organization) for logistical support. T. Brey and F. Weigt provided comments on an earlier version of this manuscript. M.S. was supported by the German National merit foundation scholarship (Studienstiftung des deutschen Volkes). This work was supported by the 'Leibniz Center for Tropical Marine Ecology (ZMT) Project Number 7109' and the 'Bremen International Graduate School for Marine Sciences (GLOMAR)'. J. Petersen provided assistance with GIS software to develop 3-dimensional maps of the creeks. Special thanks go to B. Clarke for advice on the PERMANOVA design. J. Plass-Johnson kindly proofread the manuscript.

\section{LITERATURE CITED}

Abou-Seedo F, Clayton D, Wright JM (1990) Tidal and turbidity effects on the shallow-water fish assemblage of Kuwait Bay. Mar Ecol Prog Ser 65:213-223

Al-Khayat JA, Jones DA (1999) A comparison of the macrofauna of natural and replanted mangroves in Qatar. Estuar Coast Shelf Sci 49:55-63

Allen DM, Haertel-Borer SS, Milan BJ, Bushek D, Dame RF (2007) Geomorphological determinants of nekton use of intertidal salt marsh creeks. Mar Ecol Prog Ser 329:57-71

Anderson MJ, Willis TJ (2003) Canonical analysis of principal coordinates: a useful method of constrained ordination for ecology. Ecology 84:511-525

Anderson M, Gorley R, Clarke K (2008) UK: PRIMER-E, Plymouth. PERMANOVA+ for PRIMER: guide to software and statistical methods. PRIMER-E, Plymouth

Assadi H, Dehghani P, Jahanbakhsh M (1997) Atlas of the Persian Gulf \& the Sea of Oman fishes. Iranian Fisheries Research and Training Organization, Tehran

Barletta M, Blaber SJ (2007) Comparison of fish assemblages and guilds in tropical habitats of the Embley (Indo-West Pacific) and Caeté (western Atlantic) estuaries. Bull Mar Sci 80:647-680

Barletta M, Saint-Paul U (2010) Distribution pattern of fish in a mangrove estuary. In: Saint-Paul U, Schneider H (eds) Mangrove dynamics and management in North Brazil, Book 211. Springer, Berlin

Barletta M, Barletta-Bergan A, Saint-Paul U, Hubold G (2003) Seasonal changes in density, biomass, and diversity of estuarine fishes in tidal mangrove creeks of the lower Caeté Estuary (northern Brazilian coast, east Amazon). Mar Ecol Prog Ser 256:217-228

Barletta M, Amaral CS, Corrêa MFM, Guebert F, Dantas DV, Lorenzi L, Saint-Paul U (2008) Factors affecting seasonal variations in demersal fish assemblages at an ecocline in a tropical-subtropical estuary. J Fish Biol 73:1314-1336

Blaber SJ (2000) Tropical estuarine fishes. Ecology, exploitation, and conservation. Blackwell, Oxford

Blaber SJM, Blaber TG (1980) Factors affecting the distribution of juvenile estuarine and inshore fish. J Fish Biol 17: 143-162

> Blaber S, Milton D (1990) Species composition, community structure and zoogeography of fishes of mangrove estuaries in the Solomon Islands. Mar Biol 105:259-267

Bozeman E, Dean J (1980) The abundance of estuarine larval and juvenile fish in a South Carolina intertidal creek. Estuaries 3:89-97

Chong VC, Sasekumar A, Leh MUC, D'Cruz R (1990) The fish and prawn communities of a Malaysian coastal mangrove system, with comparisons to adjacent mud flats and inshore waters. Estuar Coast Shelf Sci 31:703-722

Colwell R (2009) EstimateS: statistical estimation of species richness and shared species from samples, Version 8.2. User's guide and application. Available at: http:// purloclcorg/estimates

> Davis T (1988) Temporal changes in the fish fauna entering a tidal swamp system in tropical Australia. Environ Biol Fishes 21:161-172

Day JW (1989) Estuarine ecology. John Wiley \& Sons, New York

Desmond JS, Zedler JB, Williams GD (2000) Fish use of tidal creek habitats in two southern California salt marshes. Ecol Eng 14:233-252

> Duke N, Ball M, Ellison J (1998) Factors influencing biodi- 
versity and distributional gradients in mangroves. Glob Ecol Biogeogr Lett 7:27-47

Elliott M, Whitfield AK, Potter IC, Blaber SJM, Cyrus DP, Nordlie FG, Harrison TD (2007) The guild approach to categorizing estuarine fish assemblages: a global review. Fish Fish 8:241-268

Ellis WL, Bell SS (2008) Tidal influence on a fringing mangrove intertidal fish community as observed by in situ video recording: implications for studies of tidally migrating nekton. Mar Ecol Prog Ser 370:207-219

Faunce CH, Serafy JE (2006) Mangroves as fish habitat: 50 years of field studies. Mar Ecol Prog Ser 318:1-18

Fischer W, Bianchi G (1984) FAO species identification sheets for fishery purposes: western Indian Ocean (Fishing Area 51), Vol 5. Bony fishes: chimaeras, sharks, lobsters, shrimps and prawns, Sea turtles. FAO, Rome

Froese R, Pauly D (2012) FishBase. Available at: www.fishbase org (accessed December 2014)

Ikejima K, Tongnunui P, Medej T, Taniuchi T (2003) Juvenile and small fishes in a mangrove estuary in Trang province, Thailand: seasonal and habitat differences. Estuar Coast Shelf Sci 56:447-457

Kneib RT (1997) The role of tidal marshes in the ecology of estuarine nekton. Oceanogr Mar Biol Annu Rev 35: $163-220$

Kneib R, Wagner S (1994) Nekton use of vegetated marsh habitats at different stages of tidal inundation. Mar Ecol Prog Ser 106:227-238

Krumme U (2009) Diel and tidal movements by fish and decapods linking tropical coastal ecosystems ecological connectivity among tropical coastal ecosystems. In: Nagelkerken I (ed) Ecological connectivity among tropical coastal ecosystems. Springer, Amsterdam, p 271-324

Krumme U, Saint-Paul U (2010) Dynamics in mangrove fish assemblages on a macrotidal coast. In: Saint-Paul U, Schneider H (eds) Mangrove dynamics and management in north Brazil. Springer, Berlin, p 189-207

- Krumme U, Saint-Paul U, Rosenthal H (2004) Tidal and diel changes in the structure of a nekton assemblage in small intertidal mangrove creeks in northern Brazil. Aquat Living Resour 17:215-229

Krumme U, Grinvalds K, Zagars M, Elferts D, Ikejima K, Tongnunui $P$ (2015) Tidal, diel and lunar patterns in intertidal and subtidal mangrove creek fish assemblages from southwest Thailand. Environ Biol Fishes 98:1671-1693

Kuronuma K, Abe Y (1986) Fishes of the Arabian Gulf. Kuwait Institute for Scientific Research, Kuwait

> Laegdsgaard P, Johnson CR (1995) Mangrove habitats as nurseries: unique assemblages of juvenile fish in subtropical mangroves in eastern Australia. Mar Ecol Prog Ser 126:67-81

Laroche J, Baran E, Rasoanandrasana N (1997) Temporal patterns in a fish assemblage of a semiarid mangrove zone in Madagascar. J Fish Biol 51:3-20

Ley JA, Halliday IA (2007) Diel variation in mangrove fish abundances and trophic guilds of northeastern Australian estuaries with a proposed trophodynamic model. Bull Mar Sci 80:681-720

Ley JA, McIvor CC, Montague CL (1999) Fishes in mangrove prop-root habitats of northeastern Florida Bay: distinct assemblages across an estuarine gradient. Estuar Coast Shelf Sci 48:701-723

Lin HJ, Shao KT (1999) Seasonal and diel changes in a subtropical mangrove fish assemblage. Bull Mar Sci 65: 775-794
Little MC, Reay PJ, Grove SJ (1988) The fish community of an East African mangrove creek. J Fish Biol 32:729-747

Lugendo BR, Nagelkerken I, Kruitwagen G, van der Velde G, Mgaya YD (2007a) Relative importance of mangroves as feeding habitats for fishes: a comparison between mangrove habitats with different settings. Bull Mar Sci 80:497-512

Lugendo BR, de Groene A, Cornelissen I, Pronker A, Nagelkerken I, van der Velde G, Mgaya Y (2007b) Spatial and temporal variation in fish community structure of a marine embayment in Zanzibar, Tanzania. Hydrobiologia 586:1-16

Nagelkerken I (2009) Evaluation of nursery function of mangroves and seagrass beds for tropical decapods and reef fishes: patterns and underlying mechanisms ecological connectivity among tropical coastal ecosystems. In: Nagelkerken I (ed) Ecological connectivity among tropical coastal ecosystems. Springer, Amsterdam, p 357-399

Nagelkerken I, Dorenbosch M, Verberk WCEP, de la Morinière EC, van der Velde G (2000) Day-night shifts of fishes between shallow-water biotopes of a Caribbean bay, with emphasis on the nocturnal feeding of Haemulidae and Lutjanidae. Mar Ecol Prog Ser 194:55-64

Paterson AW, Whitfield AK (2003) The fishes associated with three intertidal salt marsh creeks in a temperate southern African estuary. Wetlands Ecol Manage 11:305-315

Quinn N, Kojis B (1987) The influence of diel cycle, tidal direction and trawl alignment on beam trawl catches in an equatorial estuary. Environ Biol Fishes 19:297-308

Robertson AI, Duke NC (1990) Mangrove fish-communities in tropical Queensland, Australia: spatial and temporal patterns in densities, biomass and community structure. Mar Biol 104:369-379

Rönnbäck P, Troell M, Kautsky N, Primavera JH (1999) Distribution pattern of shrimps and fish among Avicennia and Rhizophora microhabitats in the Pagbilao mangroves, Philippines. Estuar Coast Shelf Sci 48:223-234

Rooker JR, Dennis GD (1991) Diel, lunar and seasonal changes in a mangrove fish assemblage off southwestern Puerto Rico. Bull Mar Sci 49:684-698

- Sasekumar A, Chong VC, Leh MU, D'Cruz R (1992) Mangroves as a habitat for fish and prawns. Hydrobiologia 247:195-207

Shahraki M, Fry B (2015) Seasonal fisheries changes in lowrainfall mangrove ecosystems of Iran. Estuar Coast (in press), doi:10.1007/s12237-015-0004-x

Shahraki M, Fry B, Krumme U, Rixen T (2014) Microphytobenthos sustain fish food webs in intertidal arid habitats: a comparison between mangrove-lined and un-vegetated creeks in the Persian Gulf. Estuar Coast Shelf Sci 149: 203-212

Sheaves M (2005) Nature and consequences of biological connectivity in mangroves systems. Mar Ecol Prog Ser 302:293-305

Sheaves M, Molony B (2000) Short-circuit in the mangrove food chain. Mar Ecol Prog Ser 199:97-109

Sheppard C, Al-Husiani M, Al-Jamali F, Al-Yamani F and others (2010) The Gulf: a young sea in decline. Mar Pollut Bull 60:13-38

> Thayer GW, Colby DR, Hettler WF Jr (1987) Utilization of the red mangrove prop root habitat. Mar Ecol Prog Ser $35: 25-38$

Tongnunui $\mathrm{P}$, Ikejima $\mathrm{K}$, Yamane $\mathrm{T}$, Horinouchi $\mathrm{M}$ and others (2002) Fish fauna of the Sikao Creek mangrove estuary, Trang, Thailand. Fish Sci 68:10-17 
Vance D, Haywood ME, Heales D, Kenyon R, Loneragan N (1996) How far do prawns and fish move into mangroves? Distribution of juvenile banana prawns Penaeus merguiensis and fish in a tropical mangrove forest in northern Australia. Mar Ecol Prog Ser 131:115-124

Weis J, Weis P, MacDonald J, Pearson L (2009) Rapid changes in fish utilization of mangrove habitat in western Madagascar. Wetlands Ecol Manage 17:345-354

Willis TJ, Anderson MJ (2003) Structure of cryptic reef fish assemblages: relationships with habitat characteristics and predator density. Mar Ecol Prog Ser 257: 209-221

Editorial responsibility: Janet Ley,

St. Petersburg, Florida, USA
Wilson J, Sheaves M (2001) Short-term temporal variations in taxonomic composition and trophic structure of a tropical estuarine fish assemblage. Mar Biol 139:787-796

Wright JM (1988) Seasonal and spatial differences in the fish assemblage of the non-estuarine Sulaibikhat Bay, Kuwait. Mar Biol 100:13-20

Wright J (1989) Diel variation and seasonal consistency in the fish assemblage of the non-estuarine Sulaibikhat Bay, Kuwait. Mar Biol 102:135-142

Wright JM, Clayton DA, Bishop JM (1990) Tidal movements of shallow water fishes in Kuwait Bay. J Fish Biol 37: 959-974

Submitted: August 8, 2015; Accepted: November 6, 2015 Proofs received from author(s): December 9, 2015 